\title{
THE INFLUENZA PANDEMIC IN COLONIAL ASANTE: LESSON DRAWING FOR THE FIGHT AGAINST COVID-19 IN THE TWENTY-FIRST CENTURY
}

https://doi.org/10.52603/rec.2021.30.02

\begin{abstract}
Rezumat
Pandemia de gripă în Ashanti colonial: învăţarea de lecții pentru lupta împotriva COVID-19 în sec. XXI

Această lucrare acordă atenție strategiilor coloniale care au fost implementate pentru a lupta împotriva pandemiei de gripă printre Ashanti din Ghana. Se face o analiză comparativă a focarului și a modului de răspândire a COVID-19 în Ghana, și Ashanti, în special. În baza teoriei invățării lecțiilor, autorii au urmărit să stabilească dacă strategiile adoptate pentru combaterea pandemiei actuale COVID-19 rememorează cele anterioare, desfășurate în timpul pandemiei de gripă din 1918. Reieșind din datele primare și secundare, autorii au reconstruit o istorie care oferă câteva perspective asupra luptei împotriva COVID-19. Autorii au concluzionat că diferitele intervenții în domeniul sănătății pentru prevenirea și controlul gripei în Ashanti în perioada colonială au fost distorsionate în favoarea europenilor și băş̦inașilor care lucrau în cadrul serviciului civil colonial. Acest lucru nu a sprijinit strategiile și eforturile relevante pentru a reduce răspândirea bolii într-un ritm mai rapid. În pofida mai multor eforturi depuse pentru a reduce răspândirea bolii, administrația colonială împreună cu autoritățile tradiționale s-au confruntat cu provocări de personal sanitar inadecvat, conflict cultural, constrângeri financiare. Rolul agențiilor de securitate și colaborarea dintre administrația colonială și autoritățile locale este o lecție foarte semnificativă pentru confruntarea cu pandemia COVID-19 în Ghana.
\end{abstract}

Cuvinte-cheie: gripă, Ashanti, administrație colonială, Ghana, COVID-19, învățarea de lecții.

\section{Резюме}

Пандемия гриппа в колониальном Ашанти: извлечение уроков по борьбе с COVID-19 в XXI в.

В статье уделяется внимание колониальным стратегиям, которые применялись для борьбы с пандемией гриппа в Ашанти и в Гане, проводится сравнительный анализ вспышки и способов распространения COVID-19 в Гане и в Ашанти, в частности. Основываясь на теории извлечения уроков, авторы стремились выяснить, напоминают ли стратегии, принятые для борьбы с COVID-19, те, что применялись во время пандемии гриппа 1918 года. Опираясь на первичные и вторичные данные, авторы воссоздали историю предыдущих эпидемий гриппа, которая может помочь в борьбе с COVID-19. Авторы пришли к выводу, что различные меры по профилактике гриппа и борьбе с ним в Ашанти в колониальный период были смещены в пользу европейцев и местных жителей, которые ра- ботали на колониальной государственной службе. Это не поддерживало соответствующие стратегии и усилия по более быстрому сокращению распространения болезни. Несмотря на ряд усилий, предпринятых для сдерживания распространения болезни, колониальная администрация вместе с местными властями столкнулась с проблемами нехватки медицинского персонала, конфликта культур, финансовых ограничений. Роль органов безопасности и сотрудничество между колониальной администрацией и традиционными властями являются очень важным уроком для борьбы с пандемией COVID-19 в Гане.

Ключевые слова: грипп, Ашанти, колониальная администрация, Гана, COVID-19, извлечение урока.

\section{Summary \\ The influenza pandemic in colonial Asante: Lesson drawing for the fight against COVID-19 in the twenty-first century}

This paper pays attention to colonial strategies that were deployed to fight against the influenza pandemic among the Asante of Ghana. It does a comparative analysis of the outbreak and mode of spread of COVID-19 and influenza pandemics in Ghana and Asante, in particular. Based on the theory of lesson-drawing, the authors aimed to ascertain whether the strategies adopted to fight the current COVID-19 pandemic reminisce the earlier strategies deployed during the influenza pandemic of 1918. Based on primary and secondary data, the authors have constructed a history which proffers some insights into the fight against COVID-19. Authors conclude that the various health interventions toward the prevention and control of influenza in Asante during the colonial period were skewed in favour of Europeans and natives who worked within the colonial civil service. This did not support relevant strategies and efforts to reduce the spread of the disease at a faster pace. Despite several efforts made to curtail the spread of the disease, the colonial administration together with traditional authorities encountered challenges of inadequate health personnel, culture conflict, financial. The role of security agencies and the collaboration between the colonial administration and traditional authorities offer a very significant lesson for confronting the COVID-19 pandemic in Ghana.

Key words: Influenza, Asante, Colonial Administration, Ghana, COVID-19, Lesson Drawing.

\section{Introduction}

Infectious diseases have had adverse impact on human population for decades. Infectious diseases 
have historically manifested themselves in various forms and taken different shapes across the globe. The experience of a population with infectious diseases, depending on the magnitude and geographical space of transmission defined such outbreaks as endemic, epidemic and pandemic diseases. In January 2020, the World Health Organization (WHO) declared the COVID-19 disease as a Public Health Emergency of International Concern and later declared it a pandemic in March 2020 because of its magnitude of spread across the globe (World... 2020). Infectious diseases of similar outbreak like the recent Ebola Viral Disease (EVD), which affected most West African countries from 2013 to 2016, was declared an epidemic considering its geographical space of infection. Thus notwithstanding, there appears to be some complications in the meaning of the term pandemic. Some scholars have argued that, pandemic should be explained based on the level of explosive transmissibility, while others explain the term based on the severity of infections (Moreens et al. 2009: 1018). Over the years, people have used the term 'pandemic' to describe widespread epidemics of influenza, cholera and other diseases (Altman 2009). In a like manner, the spread of the new H1N1 swine flu influenza virus from continent to continent brought different meaning to the term. This is because the H1N1 swine flu influenza raised few questions on the meaning of pandemics; whether pandemics must be new, explosive, or severe, and whether they must be infectious at all. Moreens, Folkers and Fauci questioned the rapid spread of infectious diseases globally without causing high rates of attack (Moreens et al. 2009: 1018).

The Black Death (also known as the plaque), which killed an estimated population of 75-200 million people in the 14th century, has been regarded as the most fatal pandemic recorded in history (Wade 2020). The disease was caused by bacillus bacteria and carried by fleas on rodents; it originated in central Asia and was taken from there to the Crimea by Mongol warriors and traders (Wade 2020). Another pandemic that ravaged the world was the influenza pandemic. Gust, Hampson and Lavanchy have argued that the first documented influenza pandemic occurred in 1580, and there have been six known episodes during the last two centuries (Gust et al. 2001: 59-60). The influenza and COVID-19 pandemics have been the major pandemics that have ravaged the territories of Ghana. According to Patterson, the influenza pandemic caused great loss to the people of Ghana as the pandemic was estimated to have caused more than 100,000 deaths. Unlike COVID-19, the influenza was brought to Ghana by sea (Patterson 1981: 485). The disease was brought to Gold Coast by an American Vessel called "SS Shonga" on the 31st of August 1918. It was reported that, the spread of the disease was rapid in the territories of Gold Coast. The COVID-19 is the most current pandemic globally. The first recorded case of Covid-19 in Ghana was on the 12th of March 2020 (Ministry... 2020). Two foreigners from Turkey and Norway were the importers of the disease in Ghana.

Notwithstanding, there has been limited research on pandemics in Ghana particularly in the Asante Region. The few works on pandemics have focused on Ghana as a whole. For instance, Sambala and Manderson studied the policy perspectives on post pandemic influenza vaccination in Ghana and Malawi (Sambala et al. 2017). Patterson did a general study on the influenza pandemic in Ghana; and Cudjoe, Abdullah and Manful also did a study on the kinship care support for older people during the COVID-19 pandemic in Ghana (Patterson 1983; Gudjoe et al. 2020). Afriyie, Asare, Amponsah, and Godman did a general study on the COVID-19 pandemic in Ghana (Afriyie et al. 2020). Furthermore, few historical works on pandemics in Ghana like that of Patterson studied only the widespread nature and responses of the influenza pandemic in the Gold Coast (Patterson 1983). Kwarteng and Osei-Owusu focuses on the influenza pandemic in the Gold Coast and Asante (Kwarteng et al. 2018). His work is the closest that can be found on Asante. However, the same research leaves a significant historical gap to fill in. In particular, it does not do a comparative analysis with COVID-19 contingent related to the theory of lesson drawing. That is, no recent study has focused on the influenza pandemic and has drawn lessons for the fight against COVID-19 in Ghana and particularly on Asante within the twenty-first century.

\section{Method and Theoretical Consideration}

Information from both primary and secondary sources has been used for this study. The primary sources comprised the Public Records from the Archive Administration Department both of the Regional (Kumase) and National Archives (Accra) as well as the Manhyia Palace archives in Kumase. The data gathered supported the discussions on pandemics in Ghana, in general, and the Asante, in particular, and its associated policies in combating the spread of COVID-19 within the periods under 
review. Additionally, data were gleaned from internet sources, books and articles provided useful information for the study. The data from both the primary and secondary sources have been analysed and presented thematically to reflect the objective of the study.

Richard Rose's Lesson Drawing approach has been found to be a useful theoretical construct. According to Rose, in order to understand lesson drawing, one must understand first the meaning of the lesson (Rose 1991: 5). A lesson can be defined as an action oriented conclusion about a programme or programmes in operation elsewhere, in which the setting may include cities, organizations or countries (Rose 1991: 8). Rose further argued that the transfer of lessons from one place to another across time and space is what is termed as lesson drawing. In view of this, lesson drawing can be defined as the extent to which an effective programme or policy is transferred from one place to another. It is as a result of problem solving that gives room for lesson drawing as operative machinery. Rose also argued that each country has its own specific and unique challenges and problems. When a country is confronted with a problem, policy makers in cities and at the national level can learn from their counterparts elsewhere to enable them to respond to their problems or challenges (Rose 1991: 14). To understand lesson drawing, Rose further argued that one must have the bearing of time and space; this is because lesson drawing is contingent upon exigencies of a particular time, epoch or space (Rose 1991).

Indeed, successive policies in the past can be transferred to the present time. Space in this context justifies the transfer of a successive policy in a particular place to another. Lessons are not just drawn or borrowed from a successive programme or policy, but rather it requires singling out examples of present success of programmes and policies elsewhere. Concerning this study, we draw lessons from the strategies and outcomes that were derived during the fight against the influenza Pandemic in Asante to address and discuss the COVID-19 quandary in the region in contemporary times.

The Spread of the Influenza Pandemic and the COVID-19 in Different Epochs

Ghana, then the Gold Coast, was affected by influenza prior to 1918. The earliest recorded incidence of influenza was in the 1890's as a result of the influenza pandemic of 1889-1893 (Patterson 1983: 487). This clearly suggests that influenza was not new in the Gold Coast. Similarly, Kwarteng and
Osei-Owusu have argued that, between 1889 and 1892, the Gold Coast recorded its first cases of influenza (Kwarteng et al. 2018: 148). The 1918 influenza pandemic was brought to the Gold Coast by Sea via a vessel known as "SS Shonga". Records suggest that the vessel was infected in Sierra Leone. On the 31st of September 1918, the Vessel "SS Shonga" arrived in Secondi where most of the crew members were infected (Patterson 1983: 488). The Vessel further moved to Accra and there was reported incidence of influenza cases. Kwarteng and Osei-Owusu have also made an important assertion that the influenza pandemic of 1918 was brought to the Gold Coast not only by sea but also by the Gold Coast returnee troops from East Africa (Kwarteng et al. 2018: 148). This is because it was possible for them to be infected, since the disease was on the rise worldwide in September, the month in which they returned to the Gold Coast (Kwarteng et al 2018: 150). On 23rd September 1918, Kumase, the capital of Asante, recorded its first case of influenza. Shortly after the first recorded incidence in Kumase, the next vulnerable spots were the native hospitals where nurses and hospital attendants were brutally infected causing crisis in patient care. The disease was believed to have been brought to Kumase by road (Patterson 1983: 488).

The development of transport services in the Gold Coast facilitated the spread of the disease in Asante. Ntewusu has hinted that by the beginning of the 1900s there was a rapid development of transportation systems in the sense that, by the beginning of the 1920s road networks from the south to the north were constructed (Ntewusu 2014). The geographical location of Asante coupled with the development of transport services were the first two factors that led to the spread of the influenza in Asante. In the southern province of Asante, the disease was first recorded on the 29th of September 1918. By the middle of October 1918, almost two thirds of the population were infected especially in Obuasi $^{1}$ and its environs (Public... 1918e). The disease lasted for a period of one month in Obuasi. Statistics from the Weekly Epidemiological reports shows that over 60-70 per cent of the population were infected and almost 5 per cent of the population died from influenza. Within the Southern Province of Asante, especially in the villages, the disease was reported to have affected the population very late.

The occurrence of the disease was reported in the months of November and December. The 
location of these villages was a factor that led to the slow spread of the disease. This is in line with the Geospatial determinants of health which states that, "the location of people affects the quality of health and influences our experience with disease and well-being (Agency for Toxic Substances and Disease Registry 2020)". Since these villages were located far from the various towns and suburbs surrounding Obuasi, the pace of the spread was slow in the various villages in the Southern Province (Public... 1918e).

In Obuasi, it was reported that top European officials were among the first to have contracted the disease. The report from the Southern province to the provincial commissioner of Asante stated that, "Mr. Holmes, Senior inspector of mines, was one of the first to be affected, and both his wife (Mrs. Holmes) and himself were taken to the hospital" (Public... 1918e). Notably, figures reaching the provincial commissioner to Asante show that most of these figures were estimated. The October 1918 report from the provincial commissioner to the governor of the Gold Coast stated that, "...these figures were only approximated as many of the villages were so affected that they were unable to send massage to the Amanhene"2 (Public... 1918d). Similarly, Patterson has argued that official morbidity and mortality were conservative. Most cases were untreated and there was failure on the part of the African (traditional authorities) to report cases to the colonial administration (Patterson 1983: 488). We infer that the reasons for the provision of estimated figures were due to the poor technical and technological development at the time coupled with the medium through which the information was broadcasted.

During the early twentieth century, the Gold Coast had few sophisticated communication and transport media through which information was broadcasted. Therefore, the clerks that were sent to the various Amanhene (Paramount Chiefs) could not access most local areas every week for their report. The Amanhene were challenged with the same in getting the reports from the various Odikuro (Village heads) (Public... 1918e). It can be argued from the perspective of Patterson that, the colonial administration was reluctant towards the combat of the disease in the Gold Coast, in general, and in Asante, in particular. Reports on the influenza, which were very critical for the control of the pandemic, were controlled by the colonial administration directly. Furthermore, drawing inferences from
Patterson, most cases were untreated and there were failures on the part of African traditional authorities to perform their designated roles effectively (Patterson 1983). From this, it can be argued that the colonial administration did not provide insurance coverage for the native population during the pandemic. In support of this, Adu-Gyamfi, Dramani, Amakye-Boateng and Akomeah have argued that "the provision of health care services was initially limited to colonial administrators, officials of mining companies, merchants and other Europeans" (Adu-Gyamfi et al. 2017: 23). The 1900s to 1957 marked a strong colonial period in Ghana's history. It can be stated that, during the era of the influenza, the administration made little or no provision for healthcare coverage for the native population.

Clearly, the above discussions show that the colonial administration was a bit reluctant in the combat of the influenza pandemic for the native population in the Gold Coast and Asante, in particular. However, aside from the first two factors stated above, there were other factors that contributed to the spread of the disease in Asante. Native customs including the culture of visiting, the culture of storytelling, especially during the night, the funeral rites and marriage ceremonies played significant roles in the spread of the influenza. These customs were regulated by the concept of collectivism which was at the heart of Asante culture. Parker, Haytko and Hermans have argued that the concept of collectivism is a sub-set of cultural measures devoted to creating a society in which individuals are raised in a very strong cohesive group that protects them from outside pressure (Parker et al. 2009: 127). Within this period, the Asante were immersed in collective social, economic and political activities based on shared collective responsibility. This culture or behaviour of the people of Asante played key roles in the spread of the disease within the Asante territory.

Table 1. Weekly Report on the Death Rate in the Southern Province of Asante

\begin{tabular}{|l|l|l|}
\hline \multicolumn{1}{|c|}{ Date } & \multicolumn{1}{|c|}{ Town } & \multicolumn{1}{c|}{$\begin{array}{c}\text { No. } \\
\text { of deaths }\end{array}$} \\
\hline $2-9 / 11 / 1918$ & Akrokere & 68 \\
\hline $2-9 / 11 / 1918$ & Kokofu & 60 \\
\hline $2-9 / 11 / 1918$ & Bekwai & 24 \\
\hline $2-9 / 11 / 1918$ & Dangiasi & 63 \\
\hline
\end{tabular}

Source: (Public... 1918e) 
The above clearly shows that, the rate of infection was on the increase in the southern province of Asante as reference can be made from the death rate in these towns as shown in Table 1. Notwithstanding the above, the Northern Province of Asante had a similar situation. The Weekly Epidemiological Reports show that the Northern Province of Asante had a considerable number of cases and deaths in the month of December.

Table 2. Report on the Death Rate in the Northern Province of Asante on December 2, 1918

\begin{tabular}{|l|l|l|}
\hline \multicolumn{1}{|c|}{ Date } & \multicolumn{1}{|c|}{ Town } & \multicolumn{1}{c|}{$\begin{array}{c}\text { No. } \\
\text { of deaths }\end{array}$} \\
\hline 2nd December,1918 & Kintampo & 41 \\
\hline 2nd December,1918 & Nkoranza & 13 \\
\hline 2nd December,1918 & Banka & 30 \\
\hline 2nd December,1918 & Mo district & 30 \\
\hline
\end{tabular}

Table 2 clearly shows that the condition in the Northern Province was similar to the Southern Province of Asante. The report further stated that the above listed figures were estimated by the medical department. This was because the medical department was challenged with access to data, as most of the villages failed to report cases to the various Amanhene (Public... 1918e). The Report from the Medical Director of Health in Asante shows that the spread of the disease was intensified in the months of October and November. On 5th December 1918, Bompata (a town in the Northern Province in Asante) alone recorded 236 deaths, while Juare also recorded 83 deaths (Public... 1918a).

In Kintampo, it was recorded that by the 20th of November 1918, the territory was declared as influenza free jurisdiction (Public... 1918g). The reason for this achievement was stated in the report from the office of the provincial commissioner at Kintampo to the chief commissioner of the Asante province, "all possible precautions have been taken to prevent the spread of this scourge" (Public... 1918g). At Edweso, reported cases were horrible although there were limited numbers of reported deaths. The disease affected the entire population almost two thirds were under treatment while the remaining one third were reported to have been moving around exhibiting symptoms of the disease like coughing and snee-zing (Public... 1918b). However, despite the wide spread nature of the disease in Asante the colonial administration took practical steps to combat the disease.
Concerning COVID 19 in the twenty-first century, the Asante region follows Greater Accra with increased number of COVID-19 infections since its outbreak in Ghana (Sarpong et al. 2020). Similarly, Kenu, Frimpong and Koram have argued that the majority of the cases were in the two populated cities of Ghana, which are Accra and Kumase (Kenu et al. 2020: 72). On 28th of March 2020, partial lockdown measures were placed on some densely populated regions of Ghana (Sarpomg et al. 2020). By 28th of March 2020, the Greater Accra, the Asante and the Upper West regions reported cases of the virus and 141 cases were confirmed nationwide within the period under review (Afriyie et al. 2020: 839). After two weeks of partial lockdown, reported cases of the COVID 19 rose from 141 to 641 out of 50,000 sample tests. Out of the 641 cases, Asante recorded 53 cases while the Greater Accra region recorded 541 cases (World... 2020). On 2nd May 2020, there was an increase in the spread of the disease nationwide. Out of 2,169 cases, Asante recorded 117 cases showing an increase of 37.64 per cent from March to May 2020 (BBC... 2020). In the months of March - November 2020, there was a total of 11,131 cases in the Asante, in which 43 were active cases (National... 2020: 1). By the end of 2020 , out of 91,928 confirmed cases nationwide, the Asante region ranked the 2 nd highest recorded region of COVID 19 with 15,474 cases in the region (World... 2020).

Strategies Adopted by the Colonial Administration towards the Combat of the Influenza in Asante

Suspension of Public Activities

One of the earliest strategies employed by the colonial administration toward the combat of the influenza pandemic was the temporal ban on public activities. This strategy has been critical in contemporary times as a strategy in combating several epidemics and pandemics in the world by various governments. On 24th October 1918, the Chief Commissioner issued a communiqué to all heads of departments within the colonial administration. The report stated "owing to the serious epidemic of influenza at present, it has been found necessary to close down all schools and to discourage as much as possible public and private reunions and assemblies which might prove strong as factors for the spread of the disease" (Public... 1918c). In Asante, schools were closed by 25 th of September until further notice. Social gatherings and activities, which include funerals and marriage ceremonies, church activities among other special events like Kumase 
Red cross week, were put to a halt until further notice. Reference to this can be seen in the COVID-19 pandemic outbreak in Ghana, where there was the imposition of the Restriction Act (2020), and Act 1012. This act granted the government the power to impose lockdown measures in cities like Accra, Kumase and Kasoa. These were high risk areas that could easily cause increasing rate of infection due to their eclectic nature.

Significantly, there were instances where some District Commissioners and heads of departments were reluctant towards the advice given to them by the Chief Commissioner of Asante (Public... 1918c). On 2nd November 1918, there were reported cases of influenza throughout of Dwaso and its environs. Though the Chief Commissioner of Asante, resident in Kumase, had issued a communiqué concerning the outbreak of the influenza pandemic in Asante, including territories around the Dwaso area, the Dwaso District Commissioner waited almost unconcerned until there were some reported cases in Dwaso. Indeed, the communique was issued on 2nd October 1918 to all district heads in the Asante province but it fell on deaf ears. This escalated the rate of infections among the local population. With no equivocation, we argue that the British colonial administration erred in several instances while performing their duties to safeguard the health and social well-being of the people of Asante within the period under review (Public... 1918b).

Furthermore, the administration also concentrated on the railway, which at the time was the major transport system in the Gold Coast. Commercial trains and land borders were temporarily closed until further notice; this was because the administration saw the operation of the railway industry and the land borders as a potential threat to the spread of the influenza pandemic (Public... 1918c). Significantly, this effort did not clearly reflect in the government's action towards the fight of the COVID-19 pandemic in Ghana. Although the government of Ghana focused on spots that could catalyse the spread of the disease including the airport, seaports and social gatherings among others, limited attention was placed on land borders. It was only after the first two cases when the land borders were given the necessary attention.

\section{Protection of Frontline Workers}

Another important strategy which is consequential in contemporary times was the government attempt in protecting frontline workers, whose services were consequential towards the combat of the disease. The laws were implemented to prevent the unnecessary contact of civilians with frontline workers. Though this was a fine policy to protect the frontline workers, the law was skewed to favour the colonial administration, since it allowed the passage of non-native civilians. This is in line with the argument raised by Arhinful, who argued that health care during the colonial period was European-biased to protect their subjects from falling sick (Arhinful 2003: 8). Nurses and medical doctors were protected from the native population since their services were vital to the European population (Public... 1918f).

Public Education as a Preventive Strategy

Public education has been the major tool in ensuring good health care among a given population. Research from the Rural Health Information Hub shows that public education is designed to raise awareness on subjects that are not frequently discussed or are largely unknown to the general public. This argument reflects the social condition in Asante during the colonial period. During the period, Asante had handful elites in the society, who could read and write. This high illiteracy rate in Asante during the colonial period indicates that, general awareness on cerebral spinal meningitis (CSM) was limited. This prompted the colonial administration to organize mass educational campaign programmes that were simplified to the understanding of the masses. Chiefs, elders and the inhabitants of Asante, and for that matter Kumase, were advised by the Medical Officer of Health on the need to isolate a person suspected of coughing. Again, the Chiefs together with the people were advised to report any suspected case to the health authorities within the area. Furthermore, the Chiefs were advised to build Isolation Camps north-east in all towns and villages in other to isolate the infected persons. The natives were advised not to communicate with an infected person and isolate him or her upon seeing any sign or symptoms related to the influenza. Evidence of this can be traced currently to the COVID-19 pandemic, when mass public health educational programmes have been broadcasted through the media (Tele broadcast, Radio, Newspapers, Radio, and the Magazines) to help educate the public on the COVID-19 pandemic.

\section{Strategies Adopted by the Government of Ghana to Fight COVID-19 in the twenty-first century}

At the initial stages of the pandemic, the government of Ghana placed a temporary ban on trav- 
ellers from countries that have recorded 200 or more cases of COVID-19. This was to safeguard the health of its citizens. However, the ban was not applicable to Ghanaian citizens or foreigners with valid Ghanaian permit. On 17th March 2020, there was a mandatory two week quarantine for people entering Ghanaian territory (National... 2020: 2). Significantly, these efforts did not prove effective towards the fight against the spread of the virus in Ghana due to the late response from the government of Ghana. This is because the World Health Organization declared a Public Health Emergency of International Concerns regarding COVID-19 on 30th January 2020, and on the 11th of March 2020, it was declared as a Global pandemic by the World Health Organization (World... 2020). The above efforts could have been employed as early as possible by the government of Ghana after the emergency response from the World Health Organization.

Significantly, the lack of spot-on and immediate response strategies compelled the government to impose more intense restrictions (Afriyie et al. 2020: 840). On 22nd March 2020, the government of Ghana closed borders in the country for a period of two weeks to limit the spread of the disease. Furthermore, on 30th March 2020, the government imposed lockdown measures in Accra, Kumase and Kasoa. All public activities and gatherings were temporary banned until further notice. These restrictions were put in place by the government with the intention to reduce the spread of the COVID pandemic in Ghana.

\section{Lesson Drawing from the Influenza pan- demic for the Fight against COVID-19 in Ghana and Asante in Particular}

Lessons can be drawn from the colonial administration's efforts toward the fight against the Influenza pandemic in the Gold Coast. Lessons can be drawn from the efforts to protect frontline workers. The services from the frontline workers were vital and necessary to stabilize the health situation within the Gold Coast. In the recent pandemic, there were efforts to protect frontline workers including nurses, medical doctors, and public health officials among others who have the requisite expertise in health from contracting the disease. It can be argued that having these workers in numbers is consequential in combating the disease.

Lessons can also be drawn from the seemingly strict enforcement measures of the colonial administration. Temporal banns were placed on public spaces and activities like schools, funeral gatherings, and railway stations among others. These areas were seen as potential spots for the spread of the disease in the Gold Coast. Significantly, these restrictions were strictly enforced to ensure that the necessary protocols were observed. Similarly, COVID-19 protocols should be strictly enforced in commercial centers, public spaces, among others through the use of the law enforcement agencies such as the police. These spaces have been the vulnerable spots for the spread of the COVID-19. Employing the security agencies in these areas, the police in particular, but not the army, could compel the local population to strictly observe the protocols as proper attention was not paid to these areas during the surge of the COVID. Despite this recommendation, the question surrounding lockdowns have been problematic within the current scheme of things as a result of social challenges and economic fragility of African states including Ghana, in general, and Asante, in particular.

Again, lessons can be drawn from the colonial public education strategy that was implemented in the colonial Gold Coast. Language used in educating the people during the colonial era was simplified to the understanding of the masses especially in the rural areas. It is therefore prudent to state that public education must be strengthened especially in the various rural areas concerning the need to enforce and observe COVID-19 protocols. Though an out layer to this discussion, the malaria epidemic in Asante in particular, was curbed due to the education in local dialects especially concerning the use of quinine as a major antidote against the disease. Concerning the COVID-19 and other future epidemics or pandemics, the government of Ghana and the local government under a proper decentralized regime should ensure that such publications pertaining to how to avoid the spread of epidemics and the use of medication among other things are communicated in local dialects to the understanding of the masses especially those in the rural areas. In a long run, this will help reduce the spread of the disease and safeguard the health and well-being of the local population in Ghana and Asante, in particular.

Moreover, the security agencies and especially the military must be schooled concerning how to handle people who blatantly refuse to comply with government policies. This is necessary so that the security agencies do not end up committing a lot of infractions and disregard the individual rights of citizens, whom they are supposed to protect during such health emergencies emanating from 
the COVID-19 pandemic among others. Furthermore, there is the need to take swift and measured actions, as early as possible, when there is an outbreak of a disease in the country. Significantly, both the influenza and the COVID-19 pandemics spread out as a result of late responses from the various colonial and current governments. The influenza pandemic, for instance, was first reported in Ghana in the months of August, however, intense actions were exhibited in late September. Similarly, the current government was reluctant in the fight against COVID-19 at the initial stages of the pandemic in Ghana. The World Health Organization declared the outbreak of the COVID-19 a public health emergency in January and on the 11th of March 2020 it was officially declared as a global pandemic. During this period, the government of Ghana was reluctant to employ the necessary public health strategies to prevent the influx and the spread of the disease in the country, especially in vulnerable spots like air and sea ports, and land borders. It is against this backdrop that we can draw lessons to respond as early as possible when there is a new disease which has the potential to spread across international borders.

Also, lessons can be drawn from the indirect rule system implemented by the colonial administration. This system of government made use of the traditional institutions (chiefs, the absurdities notwithstanding), which was the emblem of political sovereignty in the Gold Coast. Since the people had respect for the chieftaincy institution at the time, particularly the centralized Asante Kingdom, the use of chiefs during epidemics to encourage and sometimes compel people to report at the hospitals for treatment impacted positively towards the combat of the diseases. The fight against the COVID-19 ought not to have been too different. The use of the traditional institution in the fight against COVID-19 has been blatantly and sometimes cunningly ignored by the government of Ghana. The new governance system and the parent law of the land, the constitution, has centralized power. The chiefs have been left almost at the periphery with the National and Regional Houses of chiefs serving as institutions that are trying to fan the flame of their lost glory with little or less meaningful impact. Several of them are accustomed to ceremonial roles in their traditional society. However, irrespective of their role in recent times, the institution is accorded maximum respect. To ensure proper decentralization, the various traditional chiefs must be given dedicated roles or functions to play in the fight against COVID-19 pandemic and any future epidemics especially in areas where the chieftaincy institution is highly rooted and respected by the local population. This will prove effective since the chieftaincy institution represents the symbol of authority of the people. Therefore, any by-laws or protocols concerning the COVID-19 could be reinforced through traditional leadership or chiefs as seen in earlier periods during the fight against the Influenza pandemic.

Furthermore, human and animal contacts must be limited especially in rural areas, where people have close proximity with animals. Over the years, animals have been transmitters of viruses and diseases to humans. Again, lessons can be drawn from the state of healthcare in the Gold Coast at the time of the influenza pandemic. The Gold Coast was not prepared for the influenza due to its limited health infrastructure. To fight the current pandemic (COVID-19) and future epidemics among others, there is the need for respective governments and stakeholders to provide adequate health or medical infrastructure, and place much emphasis on training medical personnel and the extension of public health care and their activities among the rural and urban populations in Ghana and Asante in particular.

\section{Conclusion}

The influenza pandemic in Asante had negative effects on the lives of the people. However, the presence of various health interventions within the colonial period to reduce the spread of the disease in Asante in a way was skewed in favour of the Europeans, including those who worked wi-thin the European civil service. This did not support relevant strategies and efforts to reduce the spread of the disease at a faster pace. Despite several efforts made to curtail the spread of the disease, the colonial administration together, with the traditional institutions within the period under review, encountered several challenges. Among these were inadequate personnel, culture conflict, and financial constraints among others. Despite these challenges, lessons can be drawn from these past policies and further integrate them into Ghana's current health system. The role played by the security agencies towards the combat of the disease is very useful in contemporary times, as seen during the COVID-19 pandemic in Ghana. The collaboration between the traditional authorities and the colonial administration as a result of the indirect rule system cannot be 
gainsaid. Lessons can be drawn from this policy by strengthening decentralization in Ghana. The role of the traditional institution in promoting health care and, for that matter local health, has to be strengthened to promote health care from the grassroots.

\section{Notes}

${ }^{1}$ The capital of the southern province.

${ }^{2}$ Amanhene means Paramount Chief.

\section{References}

Abdullah A., Cudjoe E. and Manful E. Creating a better kinship environment for children in Ghana: Lessons from young people with informal kinship care experience. In: Child \& Family Social Work, 2020. Vol. 25, p. 207-214.

Adu-Gyamfi S., Dramani A., Amakye-Boateng K. and Akomeah S. Public health: Socio-political history of a people. In: Journal of Arts and Humanities, 2017. Vol. 6. Issue 8, p. 12-33.

Afriyie D. K., Asare G. A., Amponsah S. K. and Godman B. Covid-19 Pandemic in Resource- Poor Countries: Challenges, Experience and Opportunities in Ghana. In: The Journal of Infections in Developing Countries, 2020. Vol. 14. Issue 8, p. 838-843.

Agency for Toxic Substances and Disease Registry (ATSDR). How Does Place Affect Health? https://www.atsdr.cdc.gov/placeandhealth/howdpesPlaceaffectHealth.html, 2020 (vizited 9.07.2021).

Altman L. K. Is this a pandemic? Define 'pandemic'. New York Times. 8 June 2009. http:// www.nytimes.com/2009/06/09/health/09docs. html (vizited 18.07.2021).

Arhinful D. K. The Solidarity of self-interest: Social and Economic Feasibility of Rural Health Insurance in Ghana. Africa Studies Centre. Leiden, 2003.

BBC News. Coronavirus: Greater Accra lead COVID-19 Infection for Ghana. https://www. bbc.com/pidgin/world-52510586, 2020 (vizited 18.07.2021).

Gust I. D., Hampson A. W. and Lavanchy D. Planning for the next pandemic of influenza. In: Reviews in Medical Virology, 2001. Vol. 11. Issue 1, p. 59-70.

Kenu E., Frimpong J. A., and Koram K. A. Responding to the COVID-19 Pandemic in Ghana. In: Ghana Medical Journal 2020. Vol. 54. Issue 2, p. 72-73.

Kwarteng K. O. and Osei-Owusu S. The Influenza Pandemic in the Gold Coast and Asante, 19181919. In: De-Valera N. Y. M Botchway and Kwame
Osei Kwarteng. Africa and the First World War: Remembrance, Memories and Representations after 100 Years. Cambridge Scholars Publishing, 2018, p. 145-163.

Ministry of Health (MOH). For immediate release: Ghana confirms two cases of COVID-19. Letter, $\mathrm{MOH} / \mathrm{OM} / 017 / 20$, 12th March, 2020.

Morens D. M., Folkers G. K. and Fauci A. S. What is a Pandemic? In: The Journal of Infectious Diseases, 2009. Vol. 200. Issue 7, p. 1018-1021.

National Narratives-Ghana. Updates on the COVID-19 pandemic in Ghana. Nov. 2020. https:// www.actuaries.org.uk/system/files/field/document/ National-Narratives-Ghana.pdf(vizited 18.07.2021).

Ntewusu S. A. Serendipity: conducting research on social history in Ghana's Archives. In: History in Africa, 2014. Vol. 41, p. 417-423.

Parker R. S., Haytko D. L. and Hermans C. M. Individualism and collectivism: Reconsidering old assumptions. In: Journal of International Business Research, 2009. Vol. 8. Issue 1, p. 127-139.

Patterson K. D. The influenza epidemic of 1918-1919 in the Gold Coast. In: The Journal of African History, 1983. Vol. 24. Issue 4, p. 485-502.

Public Records and Archives Administration (PRAAD), Kumase, ARG1/14/2/6. Report on Epidemic of Influenza in the Northern Province of Asante During the Month of October and December 1918a.

Public Records and Archives Administration (PRAAD), Kumase, ARG1/14/2/6. Correspondence between the Chief Commissioner and all Heads of Departments, 1918b.

Public Records and Archives Administration (PRAAD), Kumase, ARG1/14/2/6. Epidemics of Influenza as Spreading of, 1918c.

Public Records and Archives Administration (PRAAD), Kumase, ARG1/14/2/6. Report from the Provincial Commissioner of Asante to the Governor, 1918d.

Public Records and Archives Administration (PRAAD), Kumase, ARG1/14/2/6. Report on Epidemic of Influenza in the Southern Province of Asante During the Month of October and December, 1918 e.

Public Records and Archives Administration (PRAAD), Kumase, ARG1/14/6/2. The Chief Commissioner of Asante, $1918 \mathrm{f}$.

Public Records and Archives Administration (PRAAD), Kumase. Correspondence between the District Commissioner at Kintampo and the Chief Commissioner in Asante, 1918g. 
Rose R. What is Lesson - Drawing. In: Journal of Public Policy, 1991. Vol. 11. Issue 1, p. 3-30.

Sambala E. Z. and Manderson L. Policy perspectives on post pandemic influenza vaccination in Ghana and Malawi. In: BMC Public Health, 2017. Vol. 17. Issue 1, p. 1-13.

Sarpong T., Obeng G. Covid-19: The Ghana Case. 2020. https://www.moh.gov.gh (vizited 20.04.2020).

Wade L. From Black Death to fatal flu, past pandemics show why people on the margins suffer most. Science (2020). https://www.science.org/ news/2020/05/black-death-fatal-flu-past-pandemics-show-why-people-margins-suffer-most (vizited 20.09.2021).

World Health Organization (WHO). WHO Corona Virus Disease (COVID-19). https:// www.who. int/emergencies/disease/novel-coronavirus-2019/ situation report (vizited 19.04.2020).

Samuel Adu-Gyamfi (Kumasi, Ghana). Doctor în istorie, lector principal, șef al Departamentului de Istorie și Studii politice, Universitatea de Ştiință și Tehnologie Kwame Nkrumah.

Самуэль Аду-Гьямфи (Кумаси, Гана). Доктор истории, старший преподаватель, заведующий кафедрой истории и политических исследований, Научно-технический университет им. Кваме Нкрумы.

Samuel Adu-Gyamfi (Kumasi, Ghana). $\mathrm{PhD}$ in History, Senior Lecturer, Head of Department of History and Political Studies, Kwame Nkrumah University of Science and Technology.

E-mail: mcgyamfi@yahoo.com

ORCID: https://orcid.org/0000-0002-0193-867
Lucky Tomdi (Fredericton, Canada). Masterand in științe istorice, Universitatea din New Brunswick.

Лаки Томди (Фредериктон, Канада). Магистр истории, Университет Нью-Брансуика.

Lucky Tomdi (Fredericton, Canada). MA History student, University of New Brunswick.

E-mail: tomdilucky14@gmail.com

ORCID: https://orcid.org/0000-0002-0463-5797

Phinehas Asiamah (Kumasi, Ghana). Lector, cercetător științific, Departamentul de Istorie și Studii Politice, Universitatea de Știință și Tehnologie Kwame Nkrumah.

Пинехас Азиама (Кумаси, Гана). Преподаватель, научный сотрудник факультета истории и политических исследований Научнотехнического университета им. Кваме Нкрумы.

Phinehas Asiamah (Kumasi, Ghana). Teaching and Research Assistant, Department of History and Political Studies, Kwame Nkrumah University of Science and Technology.

Email: phinehasasiamah1@gmail.com

ORCID: https://orcid.org/0000-0002-0201-3142 